\title{
Diversity and dynamics of airborne fungi in São Luis, State of Maranhão, Brazil
}

\section{Geusa Felipa de Barros Bezerra ${ }^{[1]}$, Silvio Monteiro Gomes ${ }^{[2]}$, Marcos Antonio Custódio Neto da Silva ${ }^{[3]}$, Ramon Moura dos Santos ${ }^{[1]}$, Walbert Edson Muniz Filho ${ }^{[1]}$, Graça Maria de Castro Viana ${ }^{[1]}$ and Maria do Desterro Soares Brandão Nascimento ${ }^{[1],[4]}$}

[1]. Departamento de Patologia, Núcleo de Imunologia Básica e Aplicada, Universidade Federal do Maranhão, São Luis, MA. [2]. Departamento de Biologia, Universidade Federal do Maranhão, São Luis, MA. [3]. Curso de Medicina, Universidade Federal do Maranhão, São Luis, MA. [4]. Centro de Estudos Superiores de Caxias, Universidade Estadual do Maranhão, Caxias, MA.

\begin{abstract}
Introduction: This study aimed to identify airborne fungi in São Luis, Maranhão, Brazil, to determine the prevalent genera and to correlate these genera with the area and season. Methods: In total, 1,510 colony-forming units (CFUs) of airborne fungi were isolated from the north, south, east and west sides and from the center of the city from January to December 2007. The samples were collected on Petri dishes that were exposed to the fungi by the gravitational method. Results: Twenty genera of fungi were isolated; the most common were Aspergillus (33.5\%), Penicillium (18.8\%), Cladosporium (14.2\%), Curvularia $(10.6 \%)$ and Fusarium (7.6\%). The CFUs of the fungi were statistically significant ( $\mathrm{p}<0.0001)$. Fungal biological diversity was present all year, without any large seasonal variations but with slight increases in May, August and September. Conclusions: The fungal genera identified in this study were correlated with natural systems and could be useful when evaluating the impact of environmental changes on the region.
\end{abstract}

Keywords: Fungi. Environment. Biodiversity.

\section{INTRODUCTION}

Fungi, especially filamentous fungi, which are common aeroallergens, form a major part of bioaerosols ${ }^{1}$. Fungi are ubiquitous in outdoor air, and their concentrations, aerodynamic diameters and taxonomic compositions have potentially important implications for human health ${ }^{2}$.

The diversity and abundance of anemophilous microorganisms can be influenced by and can interfere with environmental conditions. These microorganisms are influenced by factors such as season, temperature, the relative humidity of the air and other parameters that exhibit seasonal variation ${ }^{3,4}$.

The relationships among allergic exposure, the fungal presence in indoor and outdoor environments and consequent allergic diseases are not fully understood ${ }^{5,6}$. Therefore, it is important to know both the frequency of certain airborne fungi and their distributions according to the season and the main environment (i.e., indoor or outdoor) in order to evaluate their correlations with respiratory symptoms related to allergic processes ${ }^{7-9}$.

Address to: Drª Maria do Desterro Soares Brandão Nascimento. Dept ${ }^{\circ}$ de Patologia/NIBA/UFMA. Av. dos Portugueses 1966, Prédio do CCBS, Bloco 3 , Sala 3A, Cidade Universitária do Bacanga, 65080-040 São Luis, MA, Brasil. Phone: 5598 3272-8535; Fax: 5598 3272-8535

e-mail: cnsd_ma@uol.com.br

Received 10 November 2013

Accepted 30 January 2014
These fungi can be used to assess effects on the environment and could contribute to determining the principal changes. The spores of fungi can be present in air particles and can potentially influence the hydrological cycle and climatic changes. In addition, humans are exposed daily to bioaerosols in their personal and professional lives, and these airborne particles represent a potential biological occupational hazard ${ }^{10}$. Biological particles in the air are approximately $40 \%$ organic carbon by mass and can be an important source of bioaerosols in the atmosphere above continents ${ }^{4}$. Despite the importance of airborne fungi, very little is known about their diversity ${ }^{11}$, especially of the fungi in São Luis, Maranhão.

For this reason, it was important to perform further observations to determine and characterize the frequencies of the main airborne fungi in outdoor environments and to identify possible correlations with seasonality and the possibility of monitoring allergic respiratory diseases.

\section{METHODS}

Airborne fungi were collected between January and December 2007 in five outdoor areas of the City of São Luis (northern, southern, eastern, western and central), located in the State of Maranhão, Brazil. São Luis is located at a latitude of $2^{\circ} 31^{\prime} 47^{\prime \prime} \mathrm{S}$ and a longitude of $44^{\circ} 18^{\prime} 10^{\prime \prime} \mathrm{W}$, and it is $24 \mathrm{~m}$ above sea level. This city covers an area of approximately $830 \mathrm{~km}^{2}$ and has a population of $1,017,772$ inhabitants $^{12}$. 
An analysis of the mycobiota was performed using Petri dishes $(10 \mathrm{~cm}$ by $2 \mathrm{~cm}$ ) containing $10 \mathrm{~mL}$ of Sabouraud agar medium. The dishes were exposed to open air, in selected districts and in a predetermined region, for $15 \mathrm{~min}$ every month, while placed at a height of $1.5 \mathrm{~m}$ from the ground to collect fungal spores by the action of gravity ${ }^{5,10}$. Three dishes were exposed each month in each area, resulting in a total of 15 samples per month and 180 samples per year. It is important to emphasize that the areas where the research was conducted were randomly selected. The samples used for microculture and taxonomic analysis were obtained from the colony-forming units (CFUs) ${ }^{13,14}$.

\section{Statistical analysis}

The results were analyzed using SPSS software, Chicago, USA, SPSS Inc ${ }^{\circledR}$ version 16.0 for Windows (2007). The study was cross-sectional and observational, and descriptive statistical techniques were used to assess all of the variables, with the aid of graphs and tables of frequencies. Two-tailed analysis of variance was performed to determine the relationships of the frequencies of the species (from among the five most frequent species) and the months of the year with the number of CFUs.

\section{RESULTS}

Twenty genera of fungi were isolated in this study. Depending on the region, it was possible to isolate between 10 and 14 genera, as shown in Table $1\left(\chi^{2}=535.95, \mathrm{p}<0.0001\right)$.

The main genera found in all of the regions were Aspergillus (33.5\%), Penicillium (18.8\%), Cladosporium (14.2\%), Curvularia (10.6\%) and Fusarium (7.6\%), and the detailed distributions are shown in Table 1.

Figure 1 shows that the median number of CFUs/dish during the rainy season (January to June) was 20 (maximum $=279$ and minimum $=0$ ), and the corresponding number during the dry season was 14 (maximum $=227$ and minimum $=0$ ), using the Mann-Whitney test $(\mathrm{p}=0.96)$.

A comparison of the average number of CFUs for the five most frequent fungi (Table 2), using Tukey's test, showed that the number for Aspergillus differed significantly $(\mathrm{p}<0.05)$ from the numbers for the genera Cladosporium, Curvularia and Fusarium.

TABLE 1 - Frequency distribution of colony-forming units of fungi by area in São Luis, State of Maranhão, between January and December 2007.

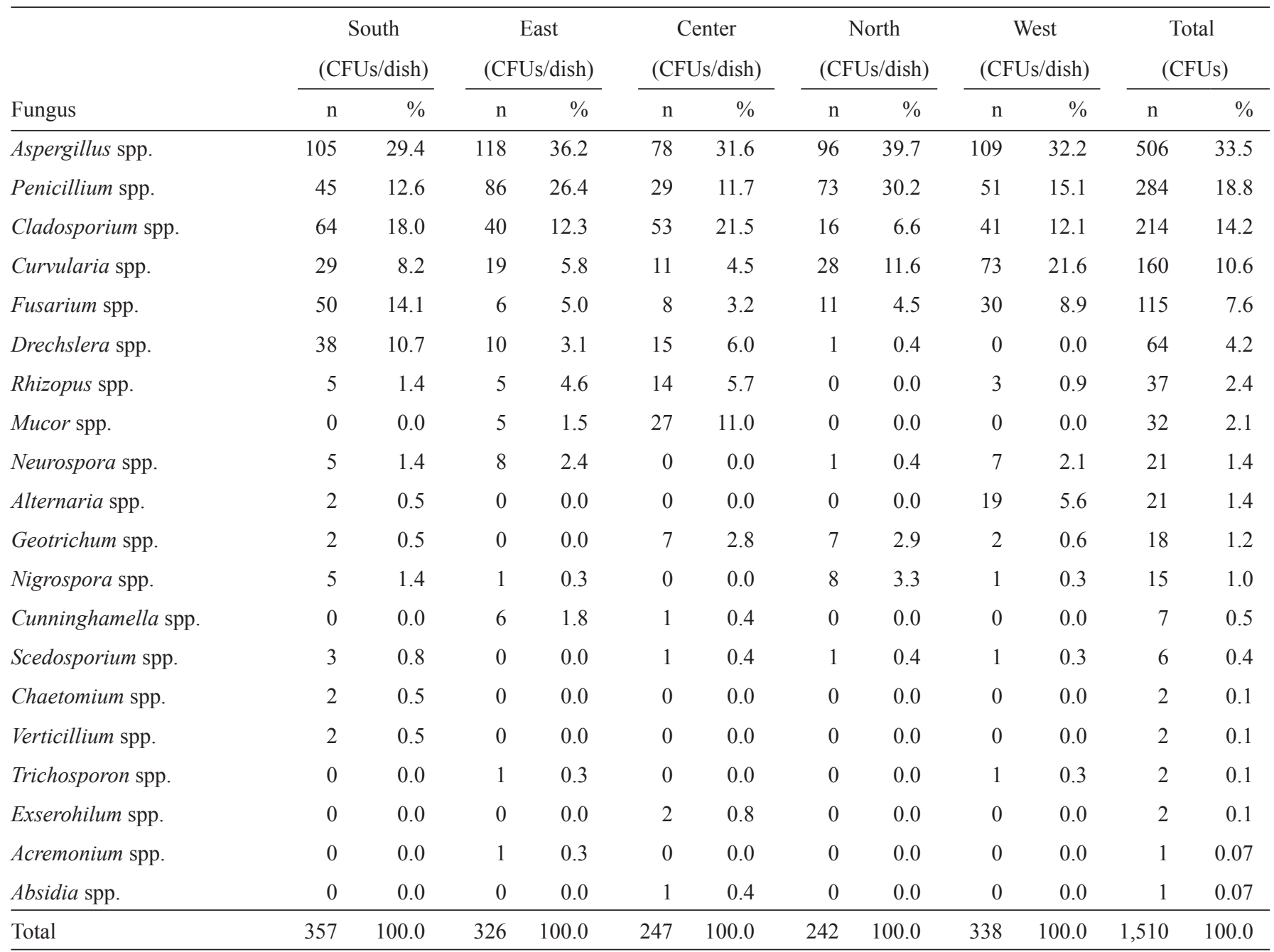

CFUs: colony-forming units. 


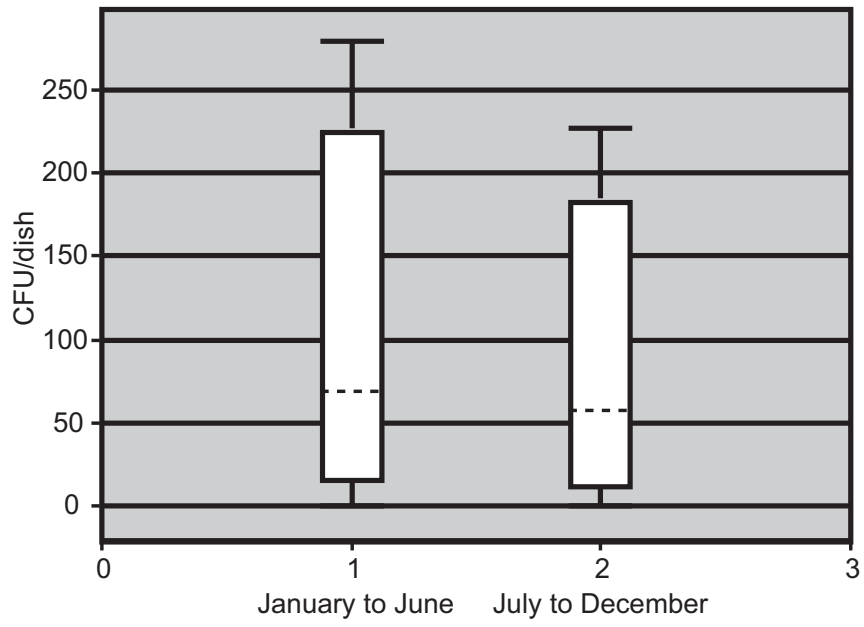

FIGURE 1 - Frequency distribution of the different genera of fungi isolated in the rainy season (January to June) and the dry season (July to December) in São Luis, State of Maranhão, between January and December 2007. Legend for Figure 1: Box plot. Medians and quartiles. CFUs per period/season. MannWhitney test, $p=0.96$. CFUs: colony-forming units.

TABLE 2 - Comparison of the average number of CFUs for the five most frequent fungi and the frequency distribution of the recovered colony-forming units of fungi by area in São Luis, State of Maranhão, between January and December 2007.

\begin{tabular}{lcc}
\hline Fungus & Average \pm SD \\
Aspergillus & $42.17 \pm 19.6$ \\
Penicillium & $23.67 \pm 12.5$ \\
Cladosporium & $17.83 \pm 22.1$ \\
Curvularia & $13.33 \pm 10.0$ \\
Fusarium & $9.58 \pm 10.8$ \\
\hline Region & Total CFUs \\
South & 357 & 23.6 \\
West & 338 & 22.4 \\
East & 326 & 21.6 \\
North & 256 & 17.0 \\
Center & 233 & 15.4 \\
Total & 1,510 & 100.0 \\
\hline
\end{tabular}

CFUs: colony-forming units; SD: standart deviation.

Regarding seasonality, we observed the occurrence of fungi throughout the year, with a slight increase in the percentages of fungal genera in the months of May, August and September (Figures 2 and 3).

When the percentages of CFUs collected in each of the five (northern, southern, central, eastern and western) areas of São Luis were analyzed, a statistically significant difference was observed (Table 2; $\chi^{2}=38.99, \mathrm{p}<0.0001$ ). The prevalence in the central and northern areas was lower than in the other areas.
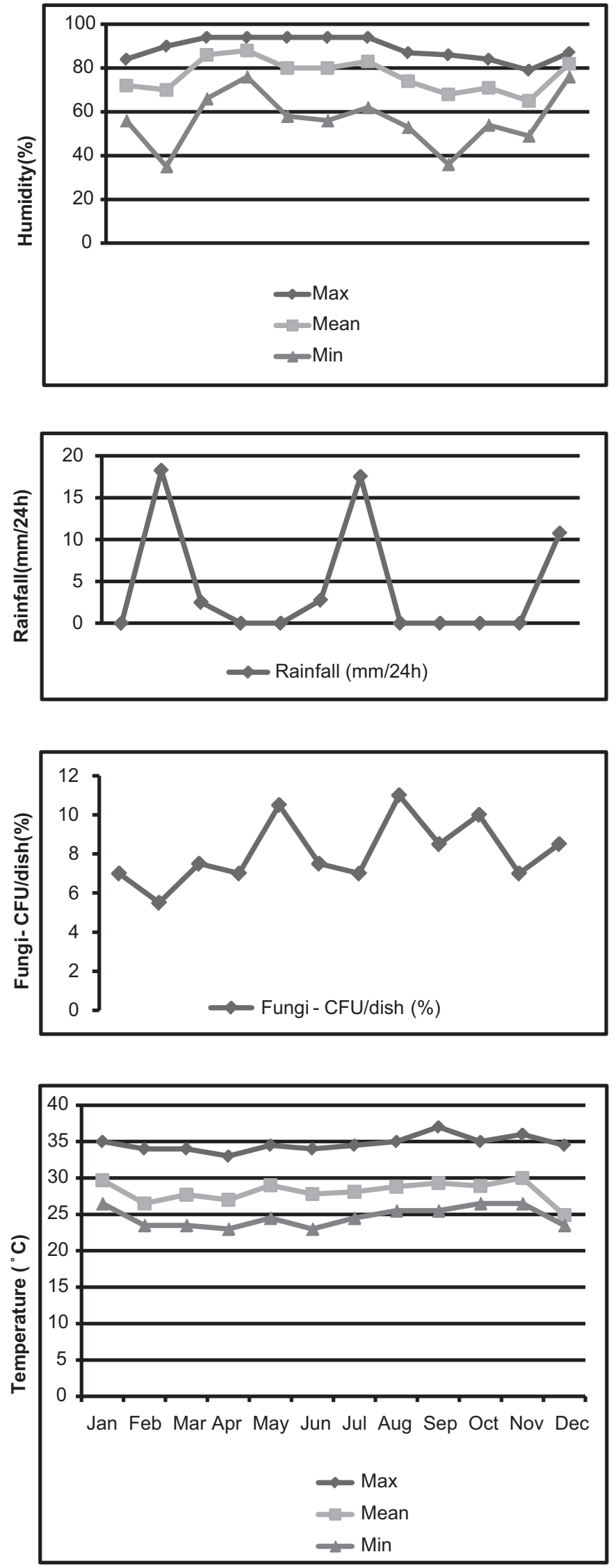

FIGURE 2 - Fungal growth and the climate variables humidity, temperature and rainfall, recorded monthly in São Luis, State of Maranhão, Brazil, in 2007. CFUs: colony-forming units. 


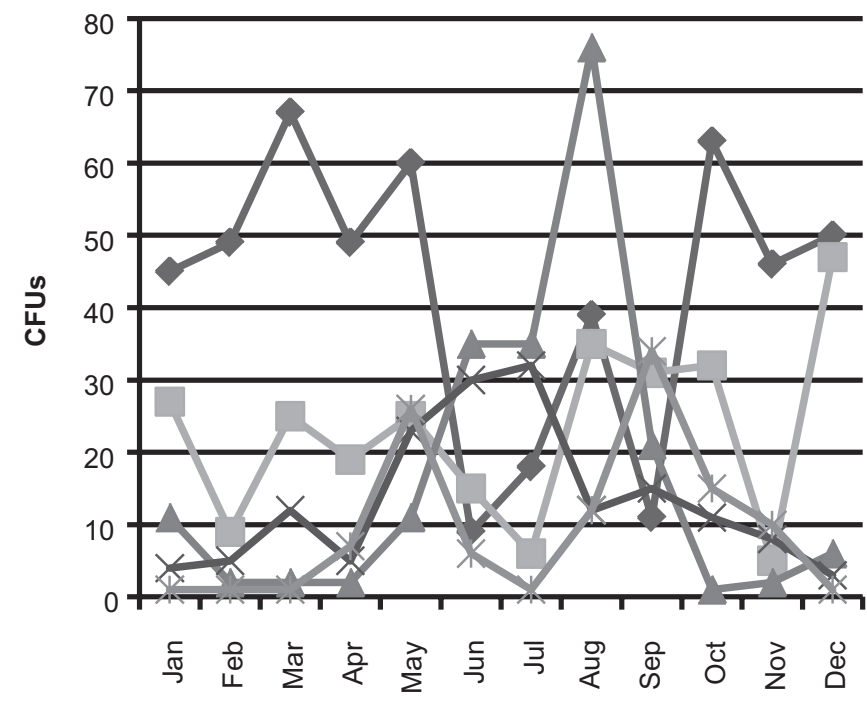

Month

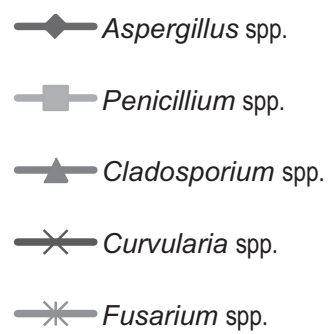

FIGURE 3 - Seasonal distribution of the five most prevalent genera isolated in São Luis, State of Maranhão, in 2007. CFUs: colony-forming units.

\section{DISCUSSION}

Aspergillus was the most commonly isolated genus in the current study, and Penicillium was the second most commonly isolated genus. In Mexico City, Penicillium is also the second most common genus ${ }^{15}$. However, in studies performed in other countries, such as France, the USA, Chile and Cuba, Cladosporium has stood out as the most prevalent genus ${ }^{16-18}$.

Aspergillus, Penicillium, Cladosporium, Curvularia and Fusarium are the most frequent outdoor species, according to previous research ${ }^{19,20}$. The genera of fungi identified in the present study were correlated with natural systems and could be useful in assessing the impact of environmental changes on the region studied.

In Brazil, the occurrence of airborne fungi in indoor and outdoor areas has been investigated in different regions $\mathbf{s}^{3,21,22}$. In the Northeast, Fortaleza, Natal and Recife are climatically similar cities. In Fortaleza, Ceará reported that the genera Aspergillus and Penicillium prevailed ${ }^{10}$. Additionally, Aspergillus and Penicillium were more frequent genera in Recife and Natal, respectively ${ }^{23,24}$. Curvularia appeared with the highest frequency only in Fortaleza ${ }^{8}$. In Belém, Pará, Aspergillus, Penicillium and Cladosporium were reported to be the most prevalent genera isolated ${ }^{25}$.

Despite differences in climate, in Porto Alegre, Rio Grande do Sul, Aspergillus was the second most frequent genus ${ }^{26}$. In Botucatu, São Paulo, Cladosporium was the most frequent genus $^{27}$. In the metropolitan area of São Paulo, Penicillium spp and Aspergillus spp. were the dominant species both indoors and outdoors ${ }^{28}$.

High relative humidity is essential for the development of fungi, and sunny weather favors the release of spores $^{29}$. High temperature and humidity can result in increased concentrations of fungi ${ }^{19}$. A high concentration of spores in the air is important because this situation can result in increases in allergic diseases of the respiratory system ${ }^{10}$.

In the South and the West, the greatest numbers of airborne fungal genera were isolated (Table 1). These regions have greater areas of vegetation covering them. The North is near the sea and presents a low level of air pollution. In Centro (CE), a small number of airborne fungi were isolated, possibly due to higher levels of pollution.

The quantitative analysis of colony counts in the northern, southern, central, eastern and western areas was statistically significant $(p=0.0002)$ when assessing the five most frequent genera relative to the months of the year. Seasonal fluctuations were also reported in Santiago, Chile ${ }^{30}$.

The literature reveals that Cladosporium has been repeatedly found indoors, particularly in house dust ${ }^{13}$. However, in the current paper, Cladosporium was found outdoors considerably more often, given that it was the second most isolated genus.

The occurrence of a great number of airborne fungi emphasizes the importance of studying airborne fungi in São Luis, Maranhão. The climate of tropical areas supports the growth of airborne fungi, resulting in high levels of fungal spores in the air, which can increase the incidence of allergic respiratory diseases related to these fungi.

\section{ACKNOWLEDGMENTS}

The authors would like to express their gratitude to Maranhão Federal University (UFMA) for allowing the use of the Applied and Basic Immunology Center (NIBA) facilities.

\section{CONFLICT OF INTEREST}

The authors declare that there is no conflict of interest.

\section{FINANCIAL SUPPORT}

This research was supported by Fundação de Amparo à Pesquisa e ao Desenvolvimento Científico e Tecnológico do Estado do Maranhão (FAPEMA). 


\section{REFERENCES}

1. Lanier C, André V, Séguin V, Heutte N, El Kaddoumi A, Bouchart V, et al. Recurrence of Stachybotrys chartarum during mycological and toxicological study of bioaerosols collected in a dairy cattle shed. Ann Agric Environ Med 2012; 19:61-67.

2. Yamamoto N, Bibby K, Qian J, Hospodsky D, Rismani-Yazdi H, Nazaroff WW, et al. Particle-size distributions and seasonal diversity of allergenic and pathogenic fungi in outdoor air. ISME J 2012; 6:1801-1811.

3. Schoenlein-Crusius IH, Trufem SFB, Grandi RAP, Milanez AI, PiresZottarelli CLA. Airborne fungi in the region of Cubatão, São Paulo State, Brazil. Braz J Microbiol 2001; 32:61-65.

4. Bowers RM, Fierer N, Horanyi E, Hannigan M, Hallar AG, Mccubbin I, et al. The contribution of biological particles to observed particulate organic carbon at a remote high altitude. Atmos Environ 2009; 43:4278-4282.

5. Bernardi E, Nascimento JS. Airborne fungi at Laranjal beach, Pelotas, Rio Grande do Sul, Brazil. Arq Inst Biol 2005; 72:93-97.

6. Pongracic JA, O'Connor JP, Muilenberg ML, Vaughn B, Gold DR, Kattan M, et al. Differential effects of outdoor versus indoor fungal spores on asthma morbidity in inner-city children. J Allergy Clin Immunol 2010; 125 : 593-599.

7. Chapman JA. How relevant are pollen and mold spore counts to clinical practice? Ann Allergy Asthma Immunol 2000; 84:467-468.

8. Bush RK, Portnoy JM, Saxon A, Terr AI, Wood RA. The medical effects of mold exposure. J Allergy Clin Immunol 2006; 117:326-333.

9. Kalyoncu F. Relationship between airborne fungal allergens and meteorological factors in Manisa City, Turkey. Environ Monit Assess 2010; 165:553-558.

10. Menezes EA, Trindade ECR, Costa MM, Freire CCF, Cavalcante MS, Cunha FA. Airborne fungi isolated from Fortaleza city, State of Ceará, Brazil. Rev Inst Med Trop São Paulo 2004; 46:133-137.

11. Fröhlich-Nowoisky J, Pickersgill DA, Després VR, Pöschl U. Hight diversity of fungi in air particulate matter. Proc Natl Acad Sci U S A 2009; 106:12814-12819.

12. Instituto Brasileiro De Geografia e Estatística (IBGE). Cidades. [Cited 2007 October 10]. Available at: http://www.ibge.g.,ov.br/cidadesat/ painel/ painel.php?codmun $=210300 \# /$.

13. Riddel RW. Permanent stained mycological preparations obtained by slide culture. Mycologia 1950; 42:265-270.

14. De Hoog GS, Guarro J, Gené J, Figueras MJ. Atlas of clinicalfungi. $2^{\text {nd }}$ edition. Utrecht, The Netherlands: Centraal bureau voor Schimmelcultures; 2000.

15. Rosas I, Calderón C, Ulloa M, Lacey J. Abundance of airborne Penicillium $\mathrm{CFU}$ in relation to urbanization in México City. Appl Environ Microbiol $1993 ; 59: 2648-2652$.
16. Pitkranta M, Meklin T, Hyvärinen A, Paulin L, Auvinen P, Nevalainen A, et al. Analysis of fungal flora in indoor dust by ribosomal DNA sequence analysis, quantitative PCR, and culture. Appl Environ Microbiol 2008; 74:233-244.

17. Sautour M, Sixt N, Dalle F, L'ollivier C, Fourquenet V, Calinon C, et al. Profiles and seasonal distribution of airborne fungi in indoor and outdoor environments at a French hospital. Sci Total Environ 2009; 407: 3766-3771.

18. Almaguer M, Aira MJ, Rodriguez, Rajo FJ, Rojas TI. Study of airborne fungus spores by viable and non-viable methods in Havana, Cuba. Taylor and Francis Online 2013; 52:289-298.

19. Kasprzyk I. Aeromycology - Main research fields of interest during the last 25 years. Ann Agric Environ Med 2008; 15:1-7.

20. Traid-Hoffman C, Jakob T, Behrendt H. Determinants of allergenicity. J Allergy Clin Immunol 2009; 123:558-566.

21. Faria A. Ecological aspects and clinical mycotic flora of anemophilus. [Doctors Thesis] [Belo Horizonte]: Universidade Federal de Minas Gerais; 1997.

22. Gambale W, Purchio A, Paula CR. Action of abiotic factors on airborne fungi in the city of Sao Paulo, Brasil. Braz J Microbiol 1983; 14:204-214.

23. Oliveira MTB, Braz RFS, Ribeiro MAG.. Airborne fungi isolated from Natal, State of Rio Grande do Norte, Brazil. Rev Microbiol (S. Paulo) 1993; 24:198-202.

24. Machado GMR. Fungos anemófilos de áreas do grande Recife. [Masters Dissertation] [Recife]: Universidade Federal de Pernambuco; 1979.

25. Pereira BFP, Melo LE, Costa PF. Fungos Anemófilos isolados na cidade de Belém, Estado do Pará - Brazil. Rev Eletr Bio 2013; 6:82-93.

26. Mezzari A, Perin C, Santos Junior SA, Bernd LAG, Di Gesu G. Airborne fungi and sensitization in atopic individuals in Porto Alegre, RS. Rev Assoc Med Bras 2003; 49:270-273.

27. Crocel J, Silva EGM, Furtado EL, Queluz THAT. Estudo dos fungos anemófilos da cidade de Botucatu e sua correlação com sensibilização em pacientes com doenças alérgicas respiratórias. Rev Bras Alerg Imunopatol 2003; 26:95-109.

28. Gonçalves FL, Bauer H, Cardoso MR, Pukinskas S, Matos D, Melhem M, et al. Indoor and outdoor atmospheric fungal spores in the São Paulo metropolitan area (Brazil): species and numeric concentrations. Int $\mathrm{J}$ Biometeorol 2010; 54:347-355.

29. Godinho R, Lanza M, Godinho A, Rodrigues A, Assiz TML. Frequency of positive skin tests for airborne allergic agents. Braz J Otorhinolaryngol 2003; 69:824-828.

30. Ibañez V, Thompson Moya L, Mañalich Muxi J. Fungal seasonal fluctuation of anemophilus fungi in Northern Santiago-Chile. Boletin Micologico 1998; 13:47-56. 